\title{
PENGEMBANGAN BUKU CERITA MENGENAI GAYA PENGAMBILAN KEPUTUSAN PADA PESERTA DIDIK KELAS XI DI SMA NEGERI 1 JAKARTA
}

\author{
Meithy Intan Rukia Luawo ${ }^{1}$ \\ Ninda Maulidya ${ }^{2}$
}

\begin{abstract}
Abstrak
Penelitian ini bertujuan untuk mengembangkan sebuah buku cerita yang berisi materi gaya pengambilan keputusan pada kelas XI di SMA Negeri 1 Jakarta. Buku cerita ini akan menjadi media penunjang pembelajaran yang dapat guru BK gunakan dalam memberikan layanan klasikal di sekolah. Jumlah populasi penelitian ini sebanyak 248 peserta didik dan jumlah sampel sebanyak 154 peserta didik. Penentuan sampel menggunakan teknik random sampling. Metode penelitian yang digunakan adalah research and development (R\&D) dengan model pengembangan ADDIE (Analyze, Design, Develop, Implement dan Evaluate). Namun, tahapan yang dilakukan hanya sampai pada tahap pengembangan. Teknik pengumpulan data menggunakan angket dan wawancara. Hasil validasi dari ahli media diperoleh sebesar $95 \%$, ahli materi sebesar $86,5 \%$ dan hasil uji coba kelompok kecil sebesar $88 \%$. Dengan demikian dapat disimpulkan bahwa media buku cerita mengenai gaya pengambilan keputusan dikategorikan sangat layak dengan dilakukan perbaikan buku cerita terdiri dari judul buku, beberapa kosakata, mengubah warna pada kotak pengenalan tokoh, memberikan kotak pada kesimpulan pada setiap akhir bagian cerita, dan menambahkan ajakan untuk berkonsultasi ke guru BK. Selain itu, media memiliki keunggulan dari media adalah warnanya yang menarik dan alur cerita yang sudah baik. Sebagian besar peserta didik juga dapat memahami nformasi mengenai gaya pengambilan keputusan pada buku cerita.
\end{abstract}

Kata Kunci: Model ADDIE, Buku Cerita, Gaya Pengambilan Keputusan

\begin{abstract}
This study aims to develop a story book that contains material decision-making styles in class XI in Jakarta 1 SMA. This storybook will be a learning support media that $B K$ teachers can use in providing classical services at school. The population of this study was 248 students and a total sample of 154 students. Determination of samples using random sampling technique. The research method used is research and development $(R \& D)$ with ADDIE (Analyze, Design, Develop, Implement and Evaluate) development models. However, the stages carried out only reached the development stage. Data collection techniques using questionnaires and interviews. The results of the validation of media experts were 95\%, material experts were $86.5 \%$ and the results of small group trials were $88 \%$. It can be concluded that the storybook media about decision-making style is categorized as very feasible by improving the storybook consisting of the title of the book, some vocabulary, changing the color in the character recognition box, giving a box to the conclusions
\end{abstract}

\footnotetext{
${ }^{1}$ Universitas Negeri Jakarta, meithyrl@unj.ac.id

${ }^{2}$ Universitas Negeri Jakarta, rikaprmtsr@ gmail.com
} 
at the end of each part of the story, and adding an invitation to consult to the BK teacher. Whereas the advantage of the media is its attractive color and good storyline. Most students can also understand information about decision-making styles in story books.

Keywords: ADDIE Model, Storybook, Decision-Making Styles

Berdasarkan Standar Kompetensi Kemandirian Pada Peserta Didik (SKKPD) disebutkan bahwa salah satu tugas perkembangan peserta didik adalah perkembangan kematangan intelektual. Kompetensi yang harus dicapai yaitu mempelajari cara-cara pengambilan keputusan dan pemecahan masalah secara objektif. Sejalan dengan itu, menurut teori perkembangan Santrock (2003) masa remaja adalah saat meningkatnya pengambilan keputusan mengenai masa depan, teman yang akan dipilih, keputusan melanjutkan belajar ke perguruan tinggi, pilihan pasangan yang akan dikencani, dan seterusnya.

Menurut Sofo, dkk. (2013) seperti teori yang menyatakan individu menampilkan gaya berpikir dan gaya belajar yang berbeda, penelitian juga menunjukkan bahwa terdapat perbedaan gaya pengambilan keputusan pada individu. Scott \& Bruce (1995) menyatakan gaya pengambilan keputusan dapat dipahami sebagai pola kebiasaan yang digunakan individu dalam pengambilan keputusan.

Driver (Baiocco, Laghi, \& D'Alessio, 2009) berpendapat melalui gaya pengambilan keputusan, dapat dipahami penyebab individu menggunakan proses keputusan yang berbeda ketika menghadapi situasi yang tampaknya identik. Pada penelitiannya, Scott \& Bruce (1995) mengidentifikasi lima gaya pengambilan keputusan yakni rational, intuitive, dependent, spontaneous dan avoidant.

Berdasarkan Studi Pendahuluan yang dilakukan di SMA Negeri 1 Jakarta ditemukan bahwa sebagian besar peserta didik belum mampu mengambil keputusan secara mandiri. Selain itu, seluruh peserta didik belum pernah mendapatkan materi mengenai gaya pengambilan keputusan.
Salah satu faktornya adalah guru BK cenderung memberikan materi secara spontan pada bimbingan klasikal. Guru BK menyesuaikan materi dengan keadaan saat ia masuk ke dalam kelas. Guru BK juga kurang cakap dalam mengimplementasikan media pembelajaran sehingga lebih sering menggunakan metode ceramah pada setiap layanan.

Menurut Sadiman, dkk. (2014) tujuan dalam proses pembelajaran yang dilakukan secara formal di sekolah adalah mencapai perkembangan optimal peserta didik secara sistematis, baik dalam aspek kognitif, afektif maupun psikomotorik. Dalam mencapai ketiga aspek tersebut diperlukannya pembelajaran guru yang menarik, menumbuhkan motivasi dan memberikan penguatan (reinforcement) pada peserta didik. Selain itu, salah satu penunjang penting pembelajaran adalah media.

Salah satu media pembelajaran yang dapat digunakan oleh guru BK adalah buku cerita. Short, dkk., (2005) berpendapat buku cerita dapat dijadikan pilihan media pembelajaran pada jenjang SMP dan SMA. Salah satu kegunaan buku cerita adalah untuk meningkatkan minat peserta didik pada suatu topik, menimbulkan daya tarik diskusi dan dapat memberikan pemahaman lebih dalam mengenai materi.

Pada hasil studi pendahuluan didapatkan data bahwa 150 peserta didik (97\%) menyatakan guru BK lebih banyak menggunakan metode ceramah; 125 peserta didik (81\%) mengungkapkan bahwa guru BK tidak menggunakan media yang menarik dan 132 peserta didik (86\%) setuju buku cerita dapat memudahkan pemahaman materi gaya pengambilan keputusan.

Hal ini memberi dampak bagi peserta didik sehingga belum mendapatkan hasil yang optimal dalam pembelajaran BK di 
kelas. Peserta didik yang sedang berada pada tahap operasional formal, memerlukan bantuan media yang menarik untuk menunjang kreativitas dan perkembangan pemikiran yang lebih abstrak. Selain itu, dengan adanya media rasa jenuh pada peserta didik dalam mengikuti pembelajaran dapat diminimalisir. Materi yang disampaikan juga menjadi lebih mudah dipahami oleh peserta didik.

Pada penelitian ini, media pembelajaran yang akan dikembangkan adalah buku cerita mengenai gaya pengambilan keputusan. Buku cerita dipilih sebab mudah digunakan untuk segala usia dan keadaan. Buku cerita tidak memerlukan alat-alat lain selain buku cerita itu sendiri. Kedua, materi yang termuat di dalam cerita akan lebih mudah dipahami dan diterima oleh peserta didik sebab disampaikan melalui alur cerita sehingga tidak terkesan menggurui.

Pada pengembangan media, peneliti menggunakan metode penelitian dan pengembangan R\&D dengan model ADDIE. Kemudian, media akan diterapkan pada layanan bimbingan klasikal. Hal ini dianggap lebih efektif, sebab dalam satu pertemuan guru BK dapat menjelaskan materi dalam satu waktu dan mencakup 3040 peserta didik.

\section{KERANGKA TEORITIK Buku Cerita}

Buku cerita tersusun atas dua kata yakni buku dan cerita. Menurut Purwardarminta (Frameswari, 2011) buku ialah beberapa helai kertas yang terjilid. Sedangkan cerita adalah narasi yang menyatakan bagaimana terjadinya suatu hal (peristiwa, kejadian dan sebagainya); rangkaian yang mengisahkan perbuatan, pengalaman atau penderitaan seseorang, kejadian dan sebagainya baik yang benar terjadi atau hanya rekaan belaka.

Matulka (2008) berpendapat dalam buku cerita bergambar, gambar-gambar melengkapi cerita, sering mencerminkan alur cerita. Sejalan dengan pendapat tersebut, Mitchel menyatakan bahwa buku cerita bergambar adalah buku yang di dalamnya terdapat gambar dan kata-kata, yang tidak berdiri sendiri, melainkan saling bergantung menjadi kesatuan cerita (Adipta, Hasanah, \& Maryaeni, 2016).

Oleh karena itu, dapat dipahami bahwa buku cerita adalah beberapa lembar kertas yang dijilid. Buku cerita tersusun atas tulisan dan gambar yang saling mendukung sehingga menghasilkan satu kesatuan penting. Di dalamnya memuat karangan peristiwa atau kejadian dan dilengkapi pesan moral yang menjadi inti sebuah cerita.

\section{Gaya Pengambilan Keputusan}

Secara sederhana pengambilan keputusan diartikan sebagai tindakan memilih diantara alternatif (Ganswein, 2011). Hapsari (2016) menyatakan pada umumnya, manusia mengambil keputusan untuk memecahkan suatu permasalahan dan mencapai tujuan tertentu dalam hidupnya.

Menurut Scott \& Bruce (1995) gaya pengambilan keputusan sebagai pola respon kebiasaan yang dipelajari dan ditunjukkan individu ketika dihadapkan dengan situasi keputusan. Ini bukan sifat kepribadian, namun kecenderungan atau kebiasaan bereaksi dengan cara tertentu dan dalam konteks keputusan tertentu. Driver (Baiocco, Laghi, \& D'Alessio, 2009) menjelaskan bahwa melalui gaya pengambilan keputusan, dapat dipahami penyebab individu menggunakan proses keputusan yang berbeda saat menghadapi situasi yang tampaknya identik.

Menurut Thunholm (Bavol'ar \& Orosova, 2015) setiap individu memiliki gaya pengambilan keputusan yang dominan pada dirinya bahkan jika mereka cenderung memiliki lebih dari satu gaya. Kecenderungan pengambilan keputusan ini disebut decision making styles yang merupakan perbedaan gaya pengambilan keputusan individu antar satu dengan lainnya (Scott \& Bruce, 1995).

Scott \& Bruce (1995) mengidentifikasi lima gaya pengambilan keputusan berdasarkan The General Decision-Making Styles Scale (GDMS). Lima gaya tersebut adalah rasional (rational), intuitif (intuitive), 
bergantung (dependent), menghindar (avoidant), spontan (spontaneous).

Gaya rasional yaitu individu yang memiliki ciri-ciri memproses informasi secara teliti sebelum mengambil keputusan, menggunakan pendekatan yang logis dan terstruktur untuk pengambilan keputusan, menyadari konsekuensi dari keputusannya sangat penting dan akan berpengaruh dalam jangka panjang.

Gaya intuitif memiliki ciri-ciri mengolah informasi tidak sistematis, ketergantungan pada firasat dan perasaan, peran yang mendominasi adalah emosi dan perasaan, individu dengan kesiapan mengambil risiko akan cenderung menggunakan intuisi untuk membuat keputusan. Sebab mereka lebih mempercayai keyakinan mereka dibanding orang lain. Gaya ini berguna ketika berada pada situasi di bawah ketidakpastian tingkat tinggi, informasi yang terbatas dan tekanan waktu.

Gaya bergantung memiliki ciri-ciri membutuhkan saran dari orang lain dalam pengambilan keputusan, Selalu merasa bergantung dan membutuhkan orang lain, Selalu mencari saran, konsultasi, dan arahan yang rinci dari orang lain yang dipercaya ketika diharuskan mengambil keputusan. Sehingga individu dengan dominan gaya bergantung dianggap relatif pasif dan berusaha untuk menghindari pengambilan keputusan. Sebab ia cenderung meminta orang lain untuk membantu memutuskan permasalahannya dibanding melakukannya sendiri.

Gaya menghindar merupakan individu yang mencoba untuk melepaskan diri dari situasi pilihan sehingga menghindari atau menunda pengambilan keputusan, memiliki sifat kebalikan dari gaya pengambilan keputusan rasional.

Gaya spontan memiliki ciri-ciri sebagai individu yang ingin mencapai sebuah keputusan dengan cepat dan selalu berusaha mengambil keputusan secepat mungkin.

\section{Model ADDIE}

Model ADDIE merupakan sebuah model yang diperkenalkan oleh Robert M. Branch untuk mengembangkan program pembelajaran. ADDIE merupakan akronim dari Analyze, Design, Development, Implementation dan Evaluation (Branch, 2009). Model ADDIE dipilih karena sudah banyak diterapkan dalam lingkungan belajar dan telah dirancang sesuai dengan tujuan pembelajaran. Ini juga didukung oleh filosofi pendidikan dalam model ADDIE yang bersifat student centered (berpusat pada peserta didik), inovatif, otentik dan inspiratif (Branch, 2009).

\section{METODE PENELITIAN Tujuan Pengembangan}

Tujuan dari penelitian adalah untuk mengembangkan media buku cerita mengenai gaya pengambilan keputusan untuk seluruh peserta didik kelas XI di SMA Negeri 1 Jakarta.

\section{Tempat dan Waktu Penelitian}

Penelitian ini dilakukan di dua tempat. Pertama, penelitian dilakukan di SMAN 1 Jakarta. Ini bertujuan untuk menemukan data kesenjangan. Tempat kedua adalah Universitas Negeri Jakarta. Ini bertujuan untuk menguji kelayakan produk hasil penelitian oleh ahli media dan ahli materi.

\section{Metode Penelitian}

Pengembangan buku cerita mengenai gaya pengambilan keputusan ini termasuk metode penelitian dan pengembangan atau research and development (R\&D). Sugiyono (2009). Secara lebih khusus, model yang digunakan pada penelitian ini adalah ADDIE. Istilah ADDIE merupakan singkatan dari Analyze, Design, Develop, Implement, and Evaluate.

\section{Populasi}

Pada penelitian ini, populasi yang dipilih adalah seluruh peserta didik kelas XI di SMAN 1 Jakarta yang berjumlah 248 peserta didik. Peserta didik terbagi ke dalam dua jurusan yaitu IPA sebanyak 120 dan IPS sebanyak 128 peserta didik. 


\section{Sampel}

Sampel yang digunakan pada penelitian ini menggunakan teknik probability sampling dengan metode yang dipilih adalah simple random sampling. Jumlah sampel yang diperlukan sebanyak 154 peserta didik.

\section{Teknik Analisis Data}

Hasil pengujian kemudian dianalisis dengan menggunakan persentase (Sugiyono, 2009).

$$
P=\frac{\text { skor hasil pengumpulan data }}{\text { skor ideal }} \times 100 \%
$$

\section{HASIL PENELITIAN}

Hasil penelitian ini menghasilkan media buku cerita mengenai gaya pengambilan keputusan untuk kelas XI di SMAN 1 Jakarta yang akan dijadikan media pembelajaran dalam layanan bimbingan klasikal. Buku cerita berhasil memenuhi tiga tahapan awal ADDIE yaitu analisis, desain dan pengembangan.

Buku cerita pada penelitian ini, termasuk kategori sangat baik berdasarkan evaluasi ahli media dan ahli materi. berdasarkan validasi media mencapai $95 \%$ yang berarti sangat baik, tingkat validasi materi mencapai $86,5 \%$. Selain itu, peneliti melakukan uji coba kelompok kecil mengenai pemahaman peserta didik terhadap materi gaya pengambilan keputusan yang ada pada buku cerita. Hasil uji coba peserta didik mencapai $88 \%$ yang berarti sangat baik.

Penelitian ini memiliki beberapa keunggulan, kelemahan serta saran yang diberikan oleh ahli media dan ahli materi. Keunggulan pada media yaitu warnanya yang menarik dan alur cerita yang sudah baik. Sedangkan kelemahan dari media adalah judulnya yang kurang menarik, hasil penjilidan buku yang mudah rusak dan terlalu formalnya beberapa kata-kata sehingga kurang cocok disisipkan di dalam buku cerita. Contohnya kata domain yang dapat diubah menjadi kata dunia, situasi atau kehidupan; menghapus kata individu; kata benar/ salah diganti tepat/tidak tepat.

Saran lain yang diberikan oleh ahli media adalah perlu adanya perbedaan antara buku cerita secara umum dengan buku cerita yang akan digunakan pada layanan BK. Hal yang dilakukan peneliti adalah menuliskan tata cara penggunaan buku cerita yang perlu dilakukan pada saat bimbingan klasikal; pembagian isu menjadi empat menyesuaikan empat bidang BK yaitu pribadi, sosial, belajar dan karir dan menyebutkan peran guru BK pada buku cerita. Ini merupakan cara untuk mewujudkan ciri khas dari buku cerita untuk layanan BK.

Selain itu, perlu dibedakan antara teks bagian cerita dengan teks bagian kesimpulan dari penulis. Peneliti mewujudkannya dengan membuat kotak untuk setiap kesimpulan di tiap bab isu. Jika terdapat perbedaan antara teori dengan hasil studi pendahuluan, pilih yang berada di tengah keduanya. Tekankan pada cerita bahwa setiap gaya pengambilan keputusan baik, yang tidak baik jika selalu dilakukan seperti itu. Masukan opsi mencari informasi lebih lanjut kepada pihak ketiga seperti guru BK atau Web tertentu. Sehingga buku cerita ini dapat menjadi medium mempromosikan layanan BK secara tidak langsung.

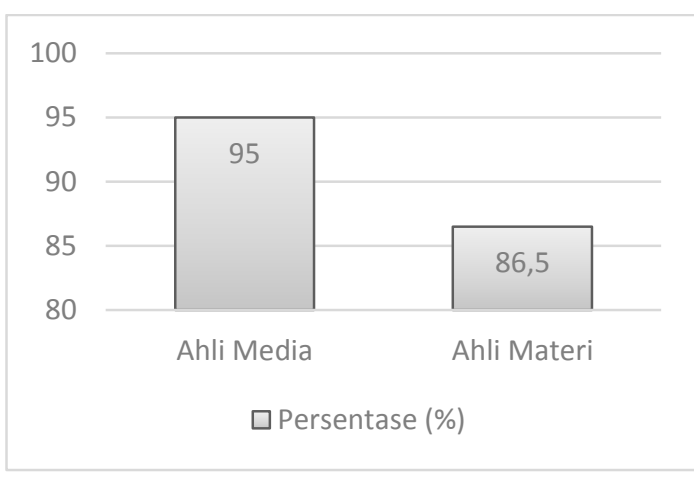

Grafik 1. Persentase Penilaian Ahli Media dan Ahli Materi 


\begin{tabular}{cllcc}
\hline No. & Nama & Jumlah & $\begin{array}{c}\text { Rata- } \\
\text { Rata }\end{array}$ & Kategori \\
\hline 1. & AJ & $83 \%$ & & \\
2. & BU & $75 \%$ & & \\
3. & MR & $92 \%$ & & \\
4. & DG & $83 \%$ & & Sangat \\
5. & D & $100 \%$ & $88 \%$ & Baik \\
6. & HF & $83 \%$ & & \\
7. & IS & $92 \%$ & & \\
8. & K & $67 \%$ & & \\
9. & MZZ & $100 \%$ & \\
10. & SRA & $100 \%$ & \\
\hline \multicolumn{5}{l}{ Tabel 1. Hasil Uji Coba Peserta Didik }
\end{tabular}

\section{KESIMPULAN}

Media pembelajaran buku cerita mengenai gaya pengambilan keputusan sudah berada pada kategori sangat baik menurut penilaian ahli media dan materi, Buku cerita memiliki beberapa keunggulan seperti alur cerita yang baik dan warna yang menarik. Namun, pengembangan ini hanya dilakukan sampai pada tahap pengembangan dan tidak memenuhi tahap implementasi dan evaluasi. Ini menyatakan media buku cerita masih memiliki kekurangan dan belum layak digunakan untuk layanan bimbingan klasikal dan perlu dilakukan pengembangan lebih lanjut untuk memperbaiki kekurangan pada media ini.

Berdasarkan penelitian yang telah dilakukan maka, saran pada penelitian yaitu:

Pengembangan media pembelajaran perlu dilakukan penelitian lebih lanjut tahap evaluasi untuk memperbaiki kekurangan yang ada pada media pembelajaran buku cerita.

Pengembangan media pembelajaran buku cerita perlu dilakukan penelitian lebih lanjut pada tahap implementasi agar dapat disesuaikan dengan keadaan yang sebenarnya pada guru BK dan peserta didik

Pada tahap validitas ahli, sebaiknya juga mengikutsertakan ahli bahasa di samping ahli media dan materi.

Penelitian ini bisa dilanjutkan dan dikembangkan pada penelitian selanjutnya dengan memperluas tujuan pembelajaran sampai ranah afektif dan psikomotorik

\section{DAFTAR PUSTAKA}

Adipta, H., Hasanah, M., \& Maryaeni. (2016) Pemanfaatan Buku Cerita Bergambar Sebagai Sumber Bacaan Siswa SD. Jurnal Pendidikan, 1(5), 989-992.

Baiocco, R., Laghi F., \& D'Alessio, M. (2009). Decision making style among adolescents: relationship with sensation seeking and locus of control. Journal of Adolescence, 32(1), 963-976.

Bavol'ar, J. \& Orosova, O. G. (2015). Decisionmaking styles and their associations with decision-making competencies and mental health. Judgment and Decision Making, 10(1), 115-122.

Branch, R M. (2009). Instructional design: The ADDIE approach. New York: Springer.

Ganswein, W. (2011). Effectiveness of information use for strategic decision making. Wiesbaden: Gabler Verlag.

Hapsari, E. E. (2016). Upaya meningkatkan kemampuan pengambilan keputusan studi lanjut melalui analisis SWOT pada siswa kelas XI IPA 4 di SMA Negeri 1 Sleman. E-Journal Bimbingan dan Konseling, 5(1), 407-418.

Matulka, D. I. (2008). A picture book primer: Understanding and using picture books. Westport: Libraries Unlimited.

Sadiman, A. S., Rahardjo, R., \& Haryono, A. (2014). Media pendidikan: Pengertian, pengembangan, dan pemanfaatannya. Jakarta: PT RajaGrafindo Persada.

Santrock, J. W. (2003). Adolescence: Perkembangan remaja. Jakarta: Erlangga.

Scott, S.G., \& Bruce, R. A. (1995). Decision making style: The development and assesment of a new measure. Educational and Psychological Measurement, 55(5), 818-831.

Short, K. G., Brown, C. L., \& Tomlison, C. M. (2005). Essentials of children's literature (8th ed.). Upper Saddle River: Pearson Education.

Sofo, F., Colapinto, C., Sofo, M., \& Ammirato, S. (2013). Adaptive Decision Making and Intellectual Styles. New York: Springer 